\title{
INNOVATION IN A PRODUCTIVE CHAIN PERSPECTIVE: COMPETENCES TO INNOVATE IN BRAZILIAN PLASTIC PACKAGING AND PETROCHEMICAL INDUSTRIES*
}

\author{
Flávia Chaves Alves ${ }^{1}$ \\ José Vitor Bomtempo \\ Paulo Coutinho ${ }^{3}$ \\ Francis Munier ${ }^{4}$
}

\begin{abstract}
This paper explores the notion of competences to innovate taking a productive chain perspective. This notion has been applied to study innovation in a very large perspective as in the case of French industrial studies or in a sectoral perspective. The originality of this paper is to deal with the concept of competences to innovate looking not only at a singular economic segment, but examining the interrelation that exists between actors that are in the same productive chain. In this way, it tries to contribute to the understanding of innovative capacity looking at the firm's internal attributes and extending those attributes to analyze the way innovation occurs in a productive chain. This paper analyses the innovation capability of the plastic productive chain studying the plastic packaging and the petrochemical in Brazil.
\end{abstract}

KEYWORDS: Competences to innovate; production chain; petrochemical; plastic packaging industry.

JEL CODE: O32; L65.

\footnotetext{
* Artigo recebido em 06/05/2011 e aprovado em 28/03/2012.

${ }^{1}$ Doutora em Gestão e Inovação Tecnológica e professora adjunta da Escola de Química da UFRJ. Contato: falves@eq.ufrj.br.

${ }^{2}$ Doutor em Economia Industrial, professor do programa de pós-graduação da Escola de Química da UFRJ e pesquisador associado do Grupo de Economia da Energia do Instituto de Economia da UFRJ. Contato: vitor@eq.ufrj.br.

${ }^{3}$ Doutor em Gestão e Inovação Tecnológica e Gerente de Inovação da BRASKEM. Contato: paulo.coutinho@ braskem.com.br.

${ }^{4}$ Doutor em Economia Aplicada e professor da Faculdade de Ciências Econômicas e de Gestão da Universidade de Strasbourg (França). Contato: fmunier@unistra.fr.
} 


\section{INOVAÇÃO SOB UMA PERSPECTIVA DA CADEIA PRODUTIVA: COMPETÊNCIAS PARA INOVAR NAS INDÚSTRIAS PETROQUÍMICA E DE EMBALAGENS PLÁSTICAS NO BRASIL}

RESUMO: Este artigo explora a capacidade inovadora de dois setores industriais no Brasil - embalagens plásticas e petroquímica utilizando a noção de competências para inovar. Examina-se a interrelação que existe entre atores que fazem parte da mesma cadeia produtiva, mas que se encontram em segmentos diferentes. A cadeia produtiva estudada envolve a indústria petroquímica, que é um importante fornecedor da indústria de embalagens plásticas. Os dois segmentos devem desempenhar papéis diferentes no processo de inovação e, consequentemente, desenvolver em maior grau competências específicas aos papéis desempenhados. Utilizaram-se questionários adaptados da proposição de François et al. (1999) que foram submetidos às firmas para avaliar o grau de desenvolvimento de um conjunto de competências. As competências são avaliadas no nível das firmas, distinguindo competências técnicas, organizacionais e relacionais. Para a indústria de embalagens plásticas é possível concluir que as deficiências na capacidade inovadora parecem residir essencialmente nas competências relacionais. No caso da petroquímica, as dificuldades encontram-se nas competências organizacionais, especialmente nas relacionadas à identificação e avaliação do conhecimento individual e coletivo. Considerando a interação entre os dois segmentos, os resultados sugerem deficiências nos níveis de competências relacionais, o que pode se refletir em dificuldades para modificar os modelos de negócios convencionais.

PALAVRAS-CHAVE: Competências para inovar; cadeia produtiva; petroquímica; embalagens plásticas. 


\section{INTRODUCTION}

This paper explores the notion of competences to innovate taking a productive chain perspective. This notion has been applied to study innovation in a very large perspective as in the case of French industrial studies (François et al., 1999; Munier, 1999, Zouhour, 2003) or in a sectoral perspective (Alves, Bomtempo and Coutinho, 2005; Munier, 2006; Le Bars, 2001). The originality of this paper is to deal with the concept of competences to innovate looking not only at a singular economic segment, but examining the interrelation that exists among actors that are in the same productive chain. Thus, it tries to contribute to innovative capacity understanding looking at the firm's internal attributes and extending those attributes to analyze the way innovation occurs in a productive chain. This paper analyses the plastic productive chain innovation capability by studying the plastic packaging and the petrochemical in Brazil.

Competences are evaluated at the firm level, distinguishing organizational, relational and technical competences. In the present case, petrochemical industry is an important supplier of plastic packaging industry and they play particularly different roles in the process of innovation if we take Pavitt's taxonomy $(1984,1990)$, for example. Petrochemical could be classified as science-based/scale intensive. On the other hand, packaging firms are typically supplier-dominated. Following this approach, the firms are expected to put emphasis in some competences to innovate, organizational, relational and technical competences, according to the sector they belong to. The petrochemical firms should put more attention on the organizational ones, once they are expected to be the functional source of innovation. The packaging firms should be able to absorb the innovations generated by their suppliers, which requires great development of relational competences. The existence of deficiencies in innovation capability of one sector would impact the whole innovation productive chain process, which is dynamic and needs the participation of different actors.

The initial proposition of François et al. (1999) allows firm's competences identification and evaluation, but do not reach singularities identification in distinct economic segments because it treats all economic segments together. Even if it is possible to consider that organizational and relational competences would not vary very much from one sector to another, technical competences appear to have deep differences. Only through a particular examination of each sector it is possible to view this kind of details. On the other hand, the economic segments do not exist separately. Suppliers and buyers relations link them and the innovation at the final consumer level is only possible if competences are rightly articulated along the productive chain.

The results, obtained by applying a questionnaire to the firms in each segment, are presented through descriptive statistical analysis followed by multiple correspondence 
analysis, taking as the start point an original research about competences to innovate in the Brazilian plastic packaging (Alves, 2005) and petrochemical (Coutinho, 2004) industries.

Their interpretation suggests some recommendations concerning the competences to innovate and firm strategies in each segment analyzed as well as a broad understanding of the relationship among them concerning innovation possibilities. To the plastic packaging sector, it is possible to conclude that the root of deficiency in innovative capacity seems to reside essentially on relational aspects. In the petrochemical, the difficulties are concentrated in organizational competences, especially in the ones related to the identification and evaluation of individual and collective knowledge. Based on this result, it is possible to perceive that efforts directed strictly to technological development would not allow an increase on innovative capacity at these sectors. It is crucial to intensify the relationship between them, concentrating efforts in competences development that provide more interaction in the productive chain.

The relational competences importance should be emphasized if we consider that firms in a productive chain could explore new business models in order to find more favorable profit appropriation forms in the innovation process. Petrochemical and packaging industries show both a similar level in relational competences. But if we decompose these competences at a quite low level, it is possible to identify two different groups: one related to the ability to collect and organize information about external environment and the other linked to the use of information for actions that will result in innovation.

In Section 2, we discuss the notion of competence to innovate in a productive chain perspective. We postulate that in order to appropriate the profit from the innovations, besides their specific competences related to their particular technological trajectory (Pavitt, 1984, 1990) or their position in the chain governance (Gereffi, Humphrey and Sturgeon, 2005), firms should mobilize competences to modify the industry architectures (Jacobides, Knudsen and Augier, 2006) and build new business models.

In Section 3, the Packaging Plastic Chain is briefly described. The methodology is presented in Section 4. The results are discussed in Section 5. Some concluding remarks are presented in Section 6.

\section{COMPETENCES to INNOVATE IN A PRODUCTIVE CHAIN PERSPECTIVE}

\subsection{THE NOTION OF COMPETENCES TO INNOVATE}

This paper explores the notion of competences as the element to distinguish firm's behavior in innovation. A relation of mutual dependence binds firm competences to 
its innovating behavior. More precisely, the firm develops competences to innovate and the innovation generates new competences. The innovation is thus carried out in feedback and implies internal and external interactions, while proceeding according to various learning modes by the means of competences increase and capitalization.

The model proposed by Kline e Rosenberg (1986) shows that the innovation proceeds by feedback between the services of $\mathrm{R} \& \mathrm{D}$, design, manufacture and marketing. The innovation is not only related to the company technological functions, it is especially a diffuse phenomenon not exclusively connected to the existence of a $\mathrm{R} \& \mathrm{D}$ laboratory. Consequently, it is the whole of competences which is determinant of the firm adaptation to its environment and of the innovative process. Productive competences, such as marketing, human resources, financing, must be thus taken into account. They express the possibility of assimilating internal and external information, of creating knowledge and of developing aptitudes to pose new problems and to bring answers there, i.e. to innovate. The importance of competences is also at the relations level, which the company with external partners weaves. Cohen and Levinthal (1990) introduce the concept of absorptive capacity to describe this phenomenon. The firm capacity (or its competence) to exploit external knowledge is crucial to develop innovation. The company is more or less qualified to seize technological opportunities and to support external interactions in order to create knowledge.

Various learning modes take part in the innovation development process, in particular "learning by doing" (Arrow, 1962), "learning by using" (Rosenberg, 1982) and "learning by interaction" (Lundvall, 1988). Learning by doing makes it possible to the individuals to acquire knowledge. In that, their competences grow rich, are renewed according to a cumulative process. According to Arrow (1962), acquired knowledge relates primarily to the technological field, but we can extend the definition to economic competences. The individuals learn by practicing and improving various operations innovation-related, thus enriching the company's competences base.

The example of necessary competence to sell the innovation illustrates this idea. The sale of a new product implies several individuals having shared tasks. Learning makes it possible for each individual to improve his/her knowledge, acquire experience, and thus become more qualified; competence which is nourished more particularly by interactions with the company's environment (competition, distribution etc.). Learning by using supports products incremental innovations development. Indeed, by taking again the model suggested by Kline e Rosenberg (1986), the new product is seldom at the point and often requires improvements, via relations with the consumers. Learning by interaction also makes it possible for the firm to support the innovation by relations with a third person, according to its capacity to adapt certain economic competences by an externalisation process. 
The recall of these points makes it possible to underline the transversal dimension of company innovation and that a whole range of competences takes part in the process of innovation. Relational competences constitute a significant part of this process.

\subsection{COMPETENCES TO INNOVATE AND THE PRODUCTIVE CHAIN}

The notion of competences to innovate has been presented as one of the tools to evaluate the innovation capacity at the firm level. Following François et al. approach (François et al., 1999), some studies have been conducted exploring firms' competences in the industrial sector as a whole (Munier, 1999) or in some particular industries (Alves, Coutinho and Bomtempo, 2005, for the Brazilian Petrochemical Industry; Alves, 2005, for the Brazilian Plastic Packaging Industry).

But as long as firm's performance takes place in a productive chain where they are inserted and perform some particular roles, some problems could be brought in consideration. How could competences to innovate, considering the relationships amongst its agents, contribute to the innovation process at the chain level? How could firms mobilize their competences in order to favor their position in terms of innovation profit appropriation? In this paper we try to go a step further considering the competences to innovate in the Brazilian Packaging Chain, in particular concerning the Petrochemical Industry and the Plastic Packaging Industry.

We start looking at the productive chain under a perspective based on the classic Pavitt's taxonomy (Pavitt, 1984, 1990). Pavitt's taxonomy has been a very influential approach to characterize sectoral differences in innovation. According to Pavitt (1984, 1990), five technological trajectories can be identified: supplier-dominated, specializedsupplier, science-based, scale-intensive and information-intensive. These different trajectories reflect differences in the main sources of technology. As a consequence, those trajectories define firm technology strategy basis. Pavitt considers that technology would be the focal point in defining firm's strategy. In the case of supplierdominated sectors, like packaging industry, technical change comes almost exclusively from suppliers, particularly machines, equipments, moulds and plastic raw materials. Two kinds of suppliers are especially relevant: machinery industry and chemical/ petrochemical industry. As new techniques tend to originate in these industries, the opportunities for firm-specific technological accumulation are weak. The focus is as a rule on improvements and modifications in production methods and inputs. Growth opportunities are seen as modest. The sector tends to have a majority of small and medium enterprises. At the strategic level, the best a firm can do is to choose and use technology from elsewhere to reinforce its competitive advantages. 
On the other hand, petrochemical firms have science-based trajectories, probably with some scale-intensive flavor. Apart from the competences to develop and incorporate in-house innovations, mostly process related innovations, developed by engineering project groups (this is, the petrochemical scale-intensive side), petrochemical firms should be able, given a science-based trajectory, to develop new knowledge and search to apply this knowledge (new or improved plastics, new applications) in order to profit from it. Concerning their relations with the packaging industry, petrochemical firms are supposed to supply new products as input to the production of new or improved packaging. In a productive chain with well defined and stable roles, Pavitt's taxonomy should indicate to a great extension the nature of competences each firm has to develop in order to provide a good innovation performance to the chain as a whole. So, if petrochemical firms show low developed competences they will fail as source of innovation to the packaging firms. Petrochemical firms are expected to excel at the organizational competences, particularly those concerning the creation of new or improved knowledge in plastics. By the same token, relational competences are central to the packaging firms in order to proceed with the inputs supplied. In the real productive chains, as illustrated in figure 1 for the Plastic Packaging case, this competences articulation tends to be quite complex, considering the number and variety of agents involved in the chain (see section 3 for a description of the plastic packaging productive chain).

Another current approach to analyze strategic roles and competences in the productive chains is based on cost transaction economics. The central point here is the notion of governance (Gereffi, Humphrey and Sturgeon, 2005). Gereffi, Humphrey and Sturgeon (2005) have studied the formation of global productive chains and tried to identify how the coordination process was distributed among the firms. A theoretical framework to help explain governance patterns in global value chains is proposed. Apart from its transaction costs economics pillar, the framework draws still on production networks, and technological capability and firm-level learning. Three variables are identified as playing a central role in determining how global value chains are governed and change: the transaction complexity, the ability to codify transactions and the capabilities in the supply-base. As a result, Gereffi, Humphrey and Sturgeon (2005), have identified five types of global value chain governance, named as hierarchy, captive, relational, modular, and market. Hierarchy governance corresponds to a high level of explicit coordination and power asymmetry and market governance stands for the lowest level of explicit coordination and power asymmetry.

Identifying the nature of value chain governance becomes then a firm's strategic task in order to adapt their competences and stay competitive. According to Gereffi, 
Humphey and Sturgeon (2005), governance in productive chains is a dynamic process, influenced by firms' strategic initiatives.

Innovation could be considered the essential strategic initiative in most industries. But, in a not-always-favorable environment, in terms of governance, how to profit from innovation? Teece, in a classical paper (Teece, 1986), proposed the possession of complementary assets as the key point in profiting from innovation. Complementary assets holders are likely to capture most of the value from innovations. Jacobides, Knudsen and Augier (2006) suggested an extension of Teece's approach with the notion of "industry architectures" i.e. "templates that emerge in a sector and circumscribe the division of labor among a set of co-specialyzed firms". According to Jacobides, Knudsen and Augier (2006), these architectures emerge usually early on in an industry's life and sometimes become stable. Firms, in some situations, may be able to modify the architecture of their sectors and to create an "architectural advantage". The creation of an architectural advantage could be possible if the firms are able to design new business models (Osterwalder, Pigneur and Tucci, 2005; Magretta, 2002). Business models have been related to the appropriating strategy in some cases (Chesbrough and Rosenbloom, 2002; Jacobides, Knudsen and Augier, 2006). If we consider the competences to innovate in a productive chain perspective, to design new business models is seen as strategic in order to change the logic of chain governance by the introduction of an innovation and possibly profiting from it. We try in the following sections to explore the competences to innovate in the Plastic Packaging chain taking in perspective two actors - petrochemical and packaging producers - which are not expected to govern the value chain in its common configuration. So, their competences to innovate could be analyzed not only regarding their specific technological trajectories but also, and with particular emphasis, their capabilities to design new business models.

\section{THE PLASTIC PACKAGING PRODUCTIVE CHAIN}

A productive chain can be defined as a system constituted by decision making agents involved in an independent process, through product and service fluxes in one way. It is constituted from feedstock suppliers, passing through transformers, distributors until final consumers (Padilha, 1999).

Plastic packaging productive chain starts with the synthesis of basic chemical products from nafta and natural gas. It is an extremely wide and complex chain (Padilha, 1999). Figure 1 represents this productive chain. 
Figure 1 - Plastic packaging productive chain

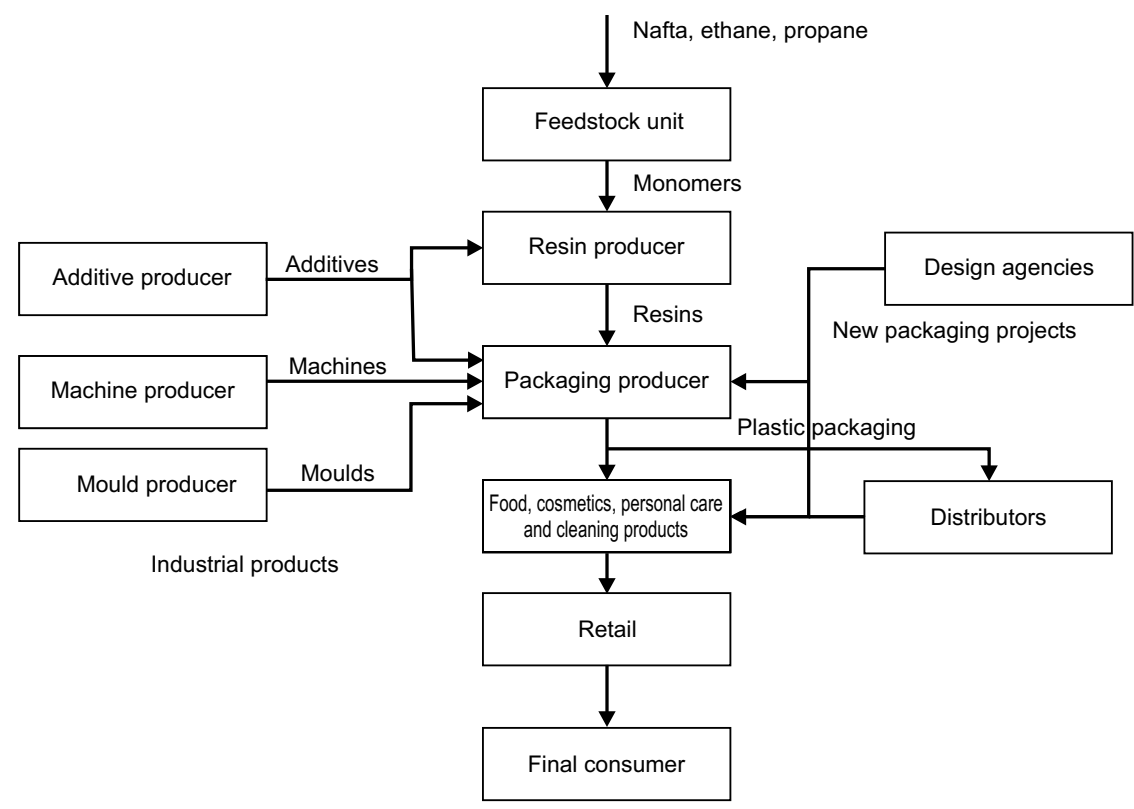

Source: Oroski (2007).

Petrochemical is a capital and scale intensive industry with large firms. Packaging producers, however, are generally small size firms. This size difference means that volume consumed by each packaging producer is very small if compared to the amount produced by petrochemical ones, which causes an intense pressure on the first ones. Fleury and Fleury (2000) assert that generally exist conflicts in the relation between packaging and petrochemical producers, mainly because of the pressure exerted by resin price on packaging producers.

There are three big industries that utilize plastic packaging: food, cosmetics, personal care and cleaning products. Food industry is the most important consumer of packaging. It is a heterogeneous economic sector, formed by large firms, which have great bargain power with suppliers, as well as by small producers. The large ones, in general, tend to specify the packaging they want, reducing the participation of packaging and petrochemical producers in what concerns innovation and differentiation.

\section{METHODOLOGY}

The data was obtained through a survey, using as data collection instrument a self-administrated questionnaire. The respondents where asked about 68 elementary competences, evaluating the degree of development of each one using a likert-type 
scale of 6 points. The questionnaire design started from a critical analysis of the general propose of François et al. (1999), including modifications in order to cover the particular aspects of innovation dynamics in each industry studied.

In the case of the packaging industry, the questionnaire was placed in a homepage accessed by a link sent by email to the respondents. A total of 212 firms were included in the sample, reaching a response rate of 33\%. For the petrochemical companies, the contact was made directly between the researcher and the respondent. The questionnaires were sent to the 11 most important petrochemical companies of national capital according to information from ABIQUIM (Associação Brasileira da Indústria Química). We obtained 9 answers, which represents $90 \%$ of the sample's billing and $75 \%$ of the total petrochemical industry, if we consider the firms with foreign share. The answers include basic, intermediate and final petrochemical producers, representing the different roles that the firms within this industry can take in the productive chain.

The research followed the methodology proposed by Fowler (1988) and Hemais (1992), being fulfilled all the steps of validation, pre-test and initial data treatment in order to assure the validity and confidence of data.

Despite of the database richness, criticisms can nevertheless be formulated on at least two points. Firstly, the investigation does not make it possible to know if the questioned firms consider that a given competence is truly necessary, in its case or generally, to develop an innovation. Secondly, certain competences are not specific to the innovation. It is then difficult to determine the objectives for which the firms developed those competences. In a general way, the competences sources question is not treated; only the possession of a repertory of competences at a given time is required.

In order to analyze the results, the elementary competences where classified according to its nature, technical, relational or organizational. The result analysis will be divided in two parts. First, we will analyze each industry separately. After that, we will proceed a comparison between the two segments, trying to understand their similarities and differences in order to understand how they affect the innovative potential of the productive chain as a whole.

\section{RESULTS}

\subsection{CHARACTERIZATION OF COMPETENCES TO INNOVATE IN EACH INDUSTRY}

First of all, it was necessary to understand the degree of development of the competences to innovate in each industry we were interested in. Table 1 shows the medium values obtained in the analysis of each industry. 
Table 1 - Medium values for technical, organizational and relational competences

\begin{tabular}{l|c|c}
\hline Variable & Petrochemical industry & Plastic packaging \\
\hline Technical competences & 3,2 & 3,2 \\
\hline Organizational competences & 2,1 & 2,9 \\
\hline Relational competences & 2,7 & 2,5 \\
\hline
\end{tabular}

In both industries, for the firms the technical competences have higher medium value than organizational ones. However, relational competences appear more developed them organizational for the firms in petrochemical industry while organizational have higher medium value than relational ones in the packaging industry. So, apparently there are some differences in the competences to innovate profile among these industries.

In order to perceive the existence of statistical differences between the medium values found within each sector, it was processed a Paired Samples T-test, with the results shown at Table 4 . To all statistic tests done in this study, it was considered a significance of $95 \%$, i.e., for $\mathrm{p}<0,05$ the null hypothesis is false.

Table 2 - Paired Samples T-test Statistics

\begin{tabular}{l|c|c}
\hline Variable & Petrochemical industry & Plastic packaging \\
\hline Technical X organizational & 0,028 & 0,00 \\
\hline Technical X relational & 0,110 & 0,00 \\
\hline Organizational X relational & 0,012 & 0,00 \\
\hline
\end{tabular}

Analyzing the results presented in Table 2 we conclude that for the packaging industry there is statistic difference between the medium values for technical and organizational competences, between technical and relational as well as between organizational and relational ones. So, technical competences are more developed than organizational which are more developed than relational ones. On the other hand, looking at the petrochemical industry, it is possible to state that technical and relational competences are in the same level, higher than the organizational competences.

If we return to Pavitt's taxonomy, considering that petrochemical could be classified as science-based and packaging as supplier-dominated, those results show that the most deficient competences for each sector are exactly the ones that appear to be more critical for the success of an innovation process in this productive chain. Petrochemical should be able to be the source of innovation, which requires developed organizational competences in order to create and diffuse knowledge. Packaging producers need to be able to absorb the innovations generated by its suppliers, which is possible only if their relational competences are well developed. The degree to which competence to innovate has been developed at the analyzed segments suggests a high difficulty to innovate that arises exactly from 
deficiencies in a competence - organizational for petrochemical and relational for plastic packaging - that is crucial for this link in the productive chain.

\subsection{COMPARISON BETWEEN INDUSTRIES}

Using the procedure of mean comparison (ONE-WAY ANOVA), it was verified that there is significant statistic difference only between organizational competences when comparing petrochemical and packaging industries, as showed in Table 3.

Table 3 - Comparison of medium values between petrochemical and packaging industries

\begin{tabular}{l|c|c|c}
\hline Variable & Petrochemical & Plastic packaging & Anova sig. \\
\hline Technical competences & 3,2 & 3,2 & 0,914 \\
\hline Organizational competences & 2,1 & 2,9 & 0,046 \\
\hline Relational competences & 2,7 & 2,5 & 0,555 \\
\hline
\end{tabular}

As the objective is to perceive the linkage between the two segments of the productive chain, we are interested in the relational components that appear to be critical for the interaction between those actors. So, a detailed analysis will be made in this group to understand more clearly what the main characteristics within this group of competences are.

It is possible to classify the relational competences of the questionnaire in two subgroups. The first one includes the competences that concern the knowledge on the external environment, that is, competences related to monitoring movements. In this group there are competences related to analysis of competing products and client needs, as well as to the setting of targets for new products. It is possible to perceive if the firm is aware of what is happening around it, if it is careful about changes and attitudes of the different actors present in its production chain. Those are competences related to the ability to collect and organize information. On the other side, there is a group of relational competences oriented to attitudes forward to the events and changes in the external environment. Those are competences linked to the use of information for actions that will result in innovations. Cooperation projects, outsourcing of certain services, collaborative actions with customers in order to devalue copies and imitations are examples of elementary competences included in that group. The descriptive analysis of those groups are shown on Table 4.

Table 4 - Comparison of medium values between petrochemical and packaging industries

\begin{tabular}{l|c|c|c|c|c|c}
\hline & \multicolumn{3}{|c|}{ Petrochemical } & \multicolumn{3}{c}{ Plastic packaging } \\
\hline Variable & Mean & Minimum & Maximum & Mean & Minimum & Maximum \\
\hline Relational competences & 2,7 & 1,4 & 4,0 & 2,5 & 1,0 & 4,6 \\
\hline Group I & 3,0 & 1,5 & 4,6 & 3,3 & 1,1 & 5,0 \\
\hline Group II & 2,4 & 1,4 & 3,9 & 2,1 & 0,3 & 4,4 \\
\hline
\end{tabular}


Within each industry there is a significant statistic difference between the medium values of these two groups of relational competences, noted by Table 5. It means that in both sectors, the firms have more developed competences related to obtaining information from the external environment than to using this information to enter in a process of innovation.

Table 5 - Paired Samples T-test Statistics for relational competences groups

\begin{tabular}{l|c|c}
\hline Variable & Petrochemical industry & Plastic packaging \\
\hline Group I X group II & 0,036 & 0,00 \\
\hline
\end{tabular}

However, if we compare the two industries for the same variable, group I and group II competences, there are no statistical differences. This analysis reveals that in this part of the productive chain - the link between petrochemical and packaging producers - the high level of development in relational competences have focused on looking outside and getting information, not on using the information to take advantage in a process of innovation.

Table 6 - Comparison of medium values between petrochemical and packaging industries

\begin{tabular}{l|c|c|c}
\hline Variable & Petrochemical & Plastic Packaging & Anova sig. \\
\hline Relational competences & 2,7 & 2,5 & 0,555 \\
\hline Group I & 3,0 & 3,3 & 0,463 \\
\hline Group II & 2,4 & 2,1 & 0,349 \\
\hline
\end{tabular}

The relational competences in the second group could be related to the capacity of creating new business models in order to modify the chain's governance and create new opportunities to innovate. So, if these sectors do not have well developed relational competences that would help in modifying the way business happens, they will always be in disadvantage compared with the other actors of the productive chain that are able to innovate and control the chain.

In a case study developed by Oroski (2007), the author describes the development of a new business model by an important petrochemical producer, called Braskem, with the intention to substitute the use of polystyrene by polypropylene in disposable products. To make it possible the use of polypropylene in this market the firm had to invest not only in the development of a resin capable to compete with polystyrene, but it also had to make an alliance with an important plastic converter, Zanatta, to create a new firm, called NTS, to produce the equipment needed to process the resin. That was necessary because the investment needed to buy the imported machine was too high and would be a strong barrier for plastic converters, and consequently, for Braskem. Clearly, the existence of relational competences of group II was definitive for Braskem's success. Firms that do not develop competences of this nature will always be limited concerning the possibilities to participate in the innovation 
process, with low economic benefits of new products created along the productive chain. If petrochemical as well as plastic packaging firms had high levels of relational competences that provided them the capacity to change the dominant business model, which is dominated by final segments - food, for example - the range of opportunities would probably be higher for them.

\section{CONCLUDING REMARKS}

This preliminary exploration of the notion of competences to innovate in a productive chain perspective has shown that the point should be studied more deeply. The results show that it is possible to understand some difficulties related to innovation if we look at the degree of development of competences to innovate not only for a particular economic sector, but for the linkage between diferent segments of the same productive chain.

Two approaches were taken. The first one has taken the notion of technological trajectory according to Pavitt's taxonomy. We examined the petrochemical industry, which is known as a science-based/scale intensive sector and should present a high level of organizational competences in order to be the source of innovation. However, the results, in the case of Brazilian petrochemical industry, depicted exactly the opposite: a low degree of organizational competences. For the plastic packaging, that is a supplier-dominated sector, the relational competences are expected to be the most important, as the firms should be able to absorb the innovation proposed by the suppliers. Nevertheless, the results clearly showed that competences of this nature were the more deficient.

The second one has taken the interaction between the two sectors looking especially at the relational competences, as these could be considered critical for the process of innovation in the productive chain. The ability to create new business models would be important for firms to appropriate the benefits of innovation and find different ways of participating in this process. For the sectors examinated, we can say that the relational competences, when divided in two different groups - getting information and using it to innovate - are at the same level for both of them. So, in order to be able to change the conventional business model and participate more intensely in the process of innovation, especially concerning the value appropriation, firms should improve their relational competences. 


\section{REFERENCES}

ALVES, F.C. Competências para inovar: um estudo a partir da indústria de embalagens plásticas. Tese de doutorado, Escola de Química, Universidade Federal do Rio de Janeiro, Rio de Janeiro, 2005.

ALVES, F.C.; BOMTEMPO, J.V.; COUTINHO, P. Competências para Inovar na Indústria Petroquímica Brasileira, Revista Brasileira de Inovação, v. 4, n. 2, jul./dec., 2005.

ARROW, K.J. The Economics Implications of Learning by Doing, Review of Economics Studies, n. 29, p. 155-173, 1962.

CHESBROUGH, H.; ROSENBLOOM, R. The role of business model in capturing value from innovation, Industrial and Corporate Change, v. 11, n. 3, p. 529-555, 2002.

COHEN, W.M.; LEVINTHAL, D.A. Absorptive Capacity: A New Perspective on Learning and Innovation, Administrative Science Quarterly, v. 35, p. 128-152, 1992.

COUTINHO, P. L. Estratégia Tecnológica e Gestão da Inovação: uma estrutura analítica voltada para os administradores das empresas. Dissertação de mestrado, Escola de Química, Universidade Federal do Rio de Janeiro, Rio de Janeiro, 2004.

FLEURY, A.; FLEURY, M.T.L. Estratégias Empresariais e Formação de Competências: Um Quebra-cabeça caleidoscópio da Indústria Brasileira. São Paulo: Editora Atlas, 2000.

FOWLER, F.J. Survey Research Methods. London: Sage Publications, 1988.

FRANÇOIS, J.P. et al. "Décrire les compétences pour l'innovation: une proposition d'enquête". In: FORAY, D.; MAIRESSE, J. (eds.) Innovations et performances, approches interdisciplinaires. Paris: Éditions EHESS, 1999.

GEREFFI, G.; HUMPHREY, J.; STURGEON, T. The governance of global value chains. Review of International Political Economy, v. 12, n. 1, p. 78-104, 2005.

HEMAIS, C. Firm-level transfer of technology: an empirical study of modes of international commercialization of technology in British industry. Tese de Doutorado, Warwick University, Coventry, England, 1992.

JACOBIDES, M.G.; KNUDSEN, T.; AUGIER, M. Benefiting from innovation: value appropriation and the role of industry architectures. Research Policy, v. 35, p. 1.200-1.221, 2006.

KLINE, S.J.; ROSENBERG, N. "Innovation: an overview”. In: LANDAU, R.; ROSENBERG, N. (eds.) The Positive Sum Strategy. Washington, D.C: National Academy Press, 1986.

LE BARS, A. Innovation sans recherche: les compétences pour innover dans les PME de lagroalimentaire. Thèse de doctorat, Université Pierre Mendès France, INRA, Grenoble, 2001.

MAGRETTA, J. Why Business Models Matter, Havard Business Review, p. 1-9, 2002.

MUNIER, F. Firm size, technological intensity of sector and relational competencies to innovate: Evidence from French industrial innovating firms, Economics of Innovation and New Technology, v. 15, n. 4-5, p. 493-505, 2006.

OROSKI, F. de A. Governança nas Cadeias Produtivas: Uma Análise da Cadeia Produtiva de Embalagens Plásticas. Dissertação de Mestrado, Escola de Química, Universidade Federal do Rio de Janeiro, Rio de Janeiro, 2007. 
OSTERWALDER, A.; PIGNEUR, Y.; TUCCI, C.L. Clarifying Business Models: Origins, Present, and Future of the Concept, Communications of the Association for Information Systems, v. 16, p. 1-25, 2005.

PADILHA, G.M.A. Competitividade da Indústria de Transformação de Plásticos: Um Estudo de Empresas do Rio de Janeiro. Tese de Mestrado em Tecnologia de Processos Químicos e Bioquímicos. Rio de Janeiro: Escola de Química, Universidade Federal do Rio de Janeiro, 1999.

PAVITT, K. Sectoral patterns of technological change: towards a taxonomy and a theory, Research Policy, v. 13, n. 6, p. 343-373, 1984.

PAVITT, K. What we know about the strategic management of technology, California Management Review, v. 32, n. 3, p. 17-26, 1990.

ZOUHOUR, K. Compétences pour innover et coopérations technologiques: Une analyse multivariée de l'industrie française, Revue d'économie industrielle, n. 102, p. 29-53, 2003. 